\title{
Cultivating equitable ground: Community-based participatory research to connect food movements with migrant farmworkers
}

\author{
Anelyse M. Weiler ${ }^{a *}$ \\ University of Toronto \\ Charles Z. Levkoe ${ }^{\mathrm{b}}$ \\ Wilfrid Laurier University \\ Carolyn Young ${ }^{\mathrm{c}}$ \\ Sustain Ontario
}

Submitted August 19, 2015 / Revised October 27, 2015 / Accepted November 16, 2015 /

Published online March 5, 2016

Citation: Weiler, A. M., Levkoe, C. Z., \& Young, C. (2016). Cultivating equitable ground:

Community-based participatory research to connect food movements with migrant

farmworkers. Journal of Agriculture, Food Systems, and Community Development, 6(2), 73-87.

http://dx.doi.org/10.5304/jafscd.2016.062.012

Copyright (C) 2016 by New Leaf Associates, Inc.

\begin{abstract}
Despite popular momentum behind North American civil society initiatives to advance social justice and ecological resilience in the food system, food movements have had limited success engaging with migrant farmworkers. This article describes a partnership between a nonprofit food

a * Corresponding author: Anelyse M. Weiler, Department of Sociology, University of Toronto; 725 Spadina Avenue; Toronto, Ontario M5S 2J4 Canada; anelyse.weiler@mail.utoronto.ca

b Charles Z. Levkoe, Department of Geography, Wilfrid Laurier University; 75 University Avenue West; Waterloo, Ontario N2L 3C5 Canada; charles.levkoe@gmail.com

c Carolyn Young, Former Director, Sustain Ontario; carolyn.cay@gmail.com
\end{abstract}

network organization in Ontario, Canada, with a mandate to advance healthy food and farming across the region and university researchers. The purpose of this community-based research was to gather a broad range of actionable ideas from key informants to advance health and equity conditions of migrant farmworkers. "Key solution ideas" were

\footnotetext{
Disclosures

Anelyse Weiler receives ongoing research support from a Pierre Elliott Trudeau Foundation 2015 Scholarship. Carolyn Young is the former director of Sustain Ontario: The Alliance for Healthy Food and Farming. In this paper, the authors discuss a community-university research partnership between Sustain Ontario and the University of Toronto. The results of this study did not provide Carolyn Young or Sustain Ontario with any monetary gain, and there were no other conflicts of interest.
} 
gathered primarily through 11 in-depth interviews and ongoing feedback from relevant actors. We reflect on the unique features of approaching this often-divisive area of inquiry through a universitycommunity partnership. Reviewing the solution ideas, we categorize proposals for advancing farmworker health and equity under four broad themes: (a) health and safety, (b) farmworker recruitment and mobility, (c) community building and social integration, and (d) immigration policy. We then critically evaluate the constraints and opportunities for addressing proposals through a network-based food organization that takes a "big tent" approach to collaborative action on polarizing issues. A tension for such organizations is taking meaningful action while avoiding overly polarizing political stances, which can alienate some members and neglect obligations to funders. Notwithstanding such tensions, communityuniversity research partnerships have the potential to expand spaces for advancing equity with farmworkers. As food networks are seeking to build meaningful alliances with migrant justice and labour movements, this study provides a timely contribution to literature and practice at the intersection of community-based participatory research, sustainable food networks, labour, and immigration.

\section{Keywords}

alternative food networks, community-based research, food movement, labour, migrant workers, sustainable food system

\section{Introduction}

For many initiatives that aim to advance a more just and sustainable food system, issues concerning migrant farmworkers are ripe with tensions. While food movements have actively focused on issues of social justice and ecological sustainability, in the eyes of farmworker advocates, supporters of these movements have been disengaged, in conflict with, or unsupportive of farmworker equity (Ramsaroop \& Wolk, 2009). Despite interests in reconnecting consumers with food producers and developing initiatives that promote appreciation of farmers, hired farmworkers have been notably absent from conversations on how to advance equitable and sustainable food systems (Ekers, Levkoe, Walker, \& Dale, 2015; Gray, 2014; Minkoff-Zern, 2014; Sbicca, 2015). This is particularly the case for those who migrate across international borders for seasonal farm employment (Hjalmarson, Bunn, Cohen, Terbasket, \& Gahman, 2015; Preibisch \& Grez, 2014; Weiler, Otero, \& Wittman, 2016). In Western Europe and North America, migrant farmworkers are rarely recognized on promotional materials for local food, invited to farm-to-table events, or represented within food policy organizations that discuss issues affecting their lives.

Ontario, ${ }^{1}$ Canada, reflects a number of these tensions: on the one hand, popular efforts are underway to promote ecological and socially just alternatives to the dominant food system; on the other hand, the economic viability of food production and processing continues to depend on migrant farmworkers who face deep-seated racial and economic inequalities. Many Canadians deem farm work an unattractive career, based on its working conditions, low levels of remuneration, rural location, and low prestige. Farm operators are faced with pressure to keep food prices low in order to compete in a globalized market, so minimizing labour costs while increasing productivity is a key strategy for maintaining viability. In addition, farm employers and farmworkers operate within a weak regulatory environment for supporting the economic viability of environmentally sound agriculture and more equitable farm labour conditions. The ensuing farm labour shortage can thus be understood as a lack of people willing to accept constrained wages, working and/or living conditions when they have viable alternatives (ReidMusson, 2014).

In response to farmers' experiences of labour shortages, migrant farmworker programs have been designed to recruit people from the Global South to work and live in Canada on a temporary basis. Because of extreme global inequalities, migrants tend to evaluate farm wages and conditions in Canada against a reference frame of poverty, a

\footnotetext{
${ }^{1}$ In Canada, labour and agriculture fall under provincial jurisdiction, while immigration is primarily the purview of the federal government.
} 
lower currency rate, and unemployment in their sending countries (Binford, 2013). Many migrants emphasize the importance of being able to support themselves and their families through Canada's temporary farmworker schemes, and 70 percent of surveyed Seasonal Agricultural Worker Program employees reported overall satisfaction with the program (Verduzco \& Lozano, 2003). Simultaneously, however, many migrants describe persistent language barriers, social isolation, unsafe and unhealthy working and living conditions, structural disregard for their knowledge and skills, discontentment with program rules, structure, and implementation, and few opportunities for integration into local communities (Basok, Bélanger, \& Rivas, 2014; Binford, 2013; Preibisch \& Otero, 2014).

Recognizing the potential for funnelling some of the resources and enthusiasm of popular food movements toward addressing local and global inequities that shape the employment of migrant farmworkers, in this article we describe a university-community partnership project that aimed to bring together a wide range of affected groups in advancing migrant farmworker health, equity, and dignity. The project was initiated jointly by Sustain Ontario, a nonprofit organization that encompasses a coalition of organizations from different sectors across the province, and researchers at the University of Toronto. Together, we were part of a community service-learning (CSL) course, gathering ideas from key informants to advance an actionable vision for equitable and viable agricultural labour for Ontario food movements. In the following section, we first set the context by explaining the circumstances of migrant farm labour and sustainable food movements in Ontario. Next, we discuss our methodologies and our initial findings, which are organized into four thematic areas that propose solutions for advancing farmworker health and equity. We conclude by discussing the implications of this research and ways in which it could be advanced. This study contributes to literature on (im)migrant farm labour policy as well as community-based participatory research. We illustrate how productive tensions inherent to community-university research partnerships can be harnessed to broaden conver- sations and alliances for advancing justice in the food system.

\section{Migrant Farmworker Employment}

In 1966 agricultural groups reporting labour shortages successfully lobbied the Canadian government to initiate a pilot migration program for temporary farm workers. Today, most migrant farmworkers in Ontario come from Mexico or Commonwealth Caribbean countries and are hired through the Seasonal Agricultural Worker Program (SAWP) (McLaughlin \& Hennebry, 2013). Today, the SAWP constitutes one of several agricultural streams of the overarching Temporary Foreign Worker Program (TFWP). The SAWP involves bilateral agreements between sending and receiving countries, with temporary work visas that last up to eight months at a time. A growing number of farmworkers, however, are hired from countries such as Guatemala, Peru, Thailand, the Philippines, and Indonesia through "low-skill" agricultural streams of the TFWP, which do not involve bilateral agreements. Farmworkers hired through these less regulated non-SAWP streams may work in Canada on 48-month work permits for a maximum of four accumulated years, after which they are ineligible for four years; this has been called the "4-and-4 Rule" (Faraday, 2014).

Proponents of the program argue that Canada's TFWP benefits migrants and their families through remittances, prevents undocumented settlement in Canada, and provides a relief valve for sending-country governments facing pressures of local poverty and unemployment (McLaughlin, 2010). In contrast to the unpopular U.S. H-2A program, Canada's agricultural TFWP is rated favourably among farmers who seek manually skilled, reliable, and affordable farm labour (Binford, 2013; Smith-Nonini, 2013). With farm employers continuing to report labour shortages each year, the program has grown from 264 farmworkers in its pilot year (1966) to approximately 45,000 in $2013^{2}$ (Employment and Social

\footnotetext{
2 This figure roughly approximates the total number of workers, representing only the number of approved Labour Market Impact Assessments. As noted by ESDC (2014): "Because SAWP workers may work for more than one
} 
Development Canada [ESDC], 2014; Satzewich, 2007). While the TFWP is premised on addressing temporary labour and skills shortages (Citizenship and Immigration Canada [CIC], 2015), it is clear that temporary migration schemes are an enduring feature of Canadian agricultural, labour, and immigration policy. Scholars have argued that at the level of Canadian corporate and foreign policy, the Canadian state is complicit in generating poverty in the Global South and thereby shaping farmworker migration practices (Walia, 2010, 2013), as in the case of two million Mexican peasants whose livelihoods were undermined by the North American Free Trade Agreement (Otero, 2011).

Critics of the TFWP point out that farmworkers are left to the arbitrary disposition of employers, government agents, and profit-seeking job recruiters with little recourse to ensure their well-being (Binford, 2013; Faraday, 2014). To be clear, our review of such critiques is not intended to vilify farmers, many of whom exemplify high standards of employee relationships, but rather to point out how temporary farm labour arrangements create structural inequalities and vulnerabilities for farmworkers. For instance, migrant farmworkers' temporary visas are tied to an individual employer, which makes it very difficult for farmworkers to transfer employers when they encounter problematic work and/or living arrangements (McLaughlin, Hennebry, \& Haines, 2014). This difficulty is compounded by migrant farmworker living accommodations, which are generally on the same site where employers work and reside (McLaughlin, 2010). Employers and sendingcountry consulates have the capacity to repatriate workers without a grievance procedure for "noncompliance, refusal to work, or any other sufficient reason" (ESDC, 2015a, Sec. X, item 1). The only mechanisms for farmworkers to ensure their job security are to receive a positive end-of-season employer evaluation and/or to be requested by an employer to return the following year. These features of the TFWP make it difficult for farm-

employer during the growing season (e.g., transfers), the total number of SAWP positions reported in this table does not reflect the actual number of seasonal workers in Canada during that period." workers to refuse employer requests for long hours or high-risk work (Binford, 2009). While researchers have documented cases of migrant farmworkers who have worked seasonally in Canada as long as three decades (Preibisch, 2012), migrants are denied access to permanent residency or citizenship and the numerous rights, entitlements, and social recognition associated with a more secure immigration status. In effect, they are both "precarious" (Faraday, 2014) and "permanently temporary" (Hennebry, 2012).

With approximately 23,000 TFWP farmworkers hired in 2013, the province of Ontario is the top employer of migrant farmworkers (ESDC, 2014). Farm labour legislation in Ontario reflects the ideology that agriculture is an "exceptional" industry because it is uniquely subject to natural variables such as weather that farmers cannot control, because it meets the fundamental human need for food, and because relatively inexpensive food costs allow wages for all other workers to remain low (Barnetson, 2009, 2012; Tucker, 2006). Proponents of agricultural exceptionalism (which is also prevalent in the United States) have consequently argued that standard labour laws should not apply to agriculture. While migrant farmworkers must be paid a minimum wage (ESDC, 2015b), they are excluded from legal minimum standards regarding maximum hours of work, overtime pay, periods of rest, eating periods, vacation, and public holidays (Ontario Ministry of Labour [OML], 2006, 2011). Prior to 2006, farmworkers were excluded from the Occupational Health and Safety Act, and they are still prevented from joining unions.

\section{Sustainable Food Networks and Migrant Justice}

Among initiatives that aim to build more socially just and ecologically resilient food systems, efforts to address farmworker inequalities have faced an array of challenges. Disproportionate whiteness and class privilege within many sustainable food initiatives tend to encourage activities based on consumption that unduly benefit relatively privileged "consumer-citizens," thereby reifying social inequalities (Bradley \& Herrera, 2015; Gibb \& Wittman, 2013; Ramírez, 2014; Turje, 2012). In 
sustainable food initiatives, consumer-citizens based in urban areas far outnumber rural food producers, and the social and geographic distance generates a lack of understanding about farmworkers' day-to-day realities. Scholars have cautioned that food movements' intense focus on promoting the social recognition of farmers can alienate farmworkers and normalize the ideology that agriculture should be exempt from basic labour standards (Weiler et al., 2016). Furthermore, a narrow focus on developing alternative food initiatives may sideline broader engagement with farmworkers embedded in the so-called industrial food system (Myers \& Sbicca, 2015).

With the aim of improving conditions for farmworkers, several food movement initiatives have focused on labeling schemes to certify that food is produced under ethically sound labour conditions. These include the Coalition of Immokalee Workers' Fair Food Program (Asbed \& Sellers, 2013), which involves partnerships with major food retailers and fast food chains; various U.S. domestic fair trade labels overseen by third-party certifiers; and the Local Food Plus label in Canada (Friedmann, 2007). Further, Canada's student-led Meal Exchange draws on the success of the U.S. Real Food Calculator for ethical food procurement in postsecondary institutions, which includes an evaluation of fair labour practices. Critical food studies scholars, however, have critiqued such "shopping for social change" strategies for reinforcing the idea that social and environmental problems can and should be addressed through the buying power of consumer-citizens (Baumann, Engman, \& Johnston, 2015; Johnston, 2008). Examining U.S. domestic fair trade schemes, Brown and Getz (2008a, 2008b) point out that these certified labels let both government and industry off the hook by privatizing regulatory functions that should apply to all employers, and not merely to those who voluntarily choose to certify (Guthman, 2007). Brown and Getz (2015) argue that certification and labeling should prompt, rather than replace, collective action and labour regulation. While endorsing such analyses, Alkon (2014) contends that within the current climate of neoliberalism, market-based strategies may also create spaces - however imperfect - for farm- workers to articulate the political changes they would like to see in the food system.

As distinct from market-focused food movement efforts, some Canadian food network organizations have recognized the need to address structural issues affecting farmworker health and equity. At the national level, for instance, the grassrootsdriven People's Food Policy document outlines a comprehensive vision for a Canada-wide food policy. It calls for "enforced legislation...to ensure that non-citizen workers on farms are fairly treated; given decent housing and wages; enjoy safe and humane working conditions; have access to health care and citizenship rights, all without reprisals" (Food Secure Canada, 2015, p. 16). As a complement to food movement organizing at the national level (e.g. Food Secure Canada, an alliance-based, pan-Canadian food organization), organizations like Sustain Ontario focus on food- and agriculture-related concerns that fall under regional and provincial jurisdiction (Levkoe, 2014). Sustain Ontario operates as a member-based nonprofit network organization that promotes healthy food and farming across diverse sectors, scales, and places. Its web of relationships makes it accountable to a range of groups, including some that have a vested interest in maintaining the status quo (e.g., farmer commodity associations).

When advocating for healthier, more equitable farmworker livelihoods, network organizations such as Sustain Ontario face both limitations and opportunities. Government authorities routinely contact members of the Sustain Ontario network to gather feedback on food and agriculture-related policy issues (Levkoe, 2014). However, the organization's reputation among provincial policy-makers as a reliable representative of diverse perspectives limits the extent to which it can endorse views that might be perceived as overly critical. Meaningfully advancing equity with migrant farmworkers would entail a radical restructuring of agriculture, labour, and immigration over the long term, but Sustain Ontario's charitable status limits the degree of political advocacy in which it can engage. Grassroots organizations preferring a more confrontational activist approach have thus criticized Sustain Ontario for not taking a stronger stance on controversial issues. Network organizations like Sustain 
Ontario often face a tension between maintaining a broad network that acknowledges multiple perspectives and articulating a single common voice (Levkoe, 2015). The advantage of Sustain Ontario's network-based, big-tent approach is that the organization is uniquely positioned to help convene collaborative action to scale-out existing communitybased efforts (i.e., generate new member initiatives) and scale-up policy shifts (i.e., address systemic challenges such as state and corporate regimes that support unsustainable forms of agriculture). Whereas other grassroots and union movements might view polarization and fragmentation as necessary consequences of dismantling the status quo for farmworkers, Sustain Ontario's mandate is to take a systems-wide approach that involves a broad range of affected groups.

\section{Methodology and Approach}

Sustain Ontario and its members have discussed issues of food and farm labour in the past, yet there has been little capacity to move any significant initiatives forward. In 2014 a communityuniversity partnership was developed with researchers at the University of Toronto through Planning for Change: Community Development in Action, a CSL course in the Department of Geography and Planning. Unlike most CSL experiences, Planning for Change is an eight-month graduatelevel class that enables community partners to develop research projects in collaboration with the students and instructors (Levkoe et al., 2014). Working together to design and implement the project, graduate student Anelyse Weiler led the research team that included Carolyn Young (then director of Sustain Ontario) and course coinstructor Charles Levkoe.

While researchers have rigorously explored the problem context of health equity and justice for migrant farmworkers, it has proved more difficult to identify constructive, actionable, and feasible solutions with broad-based buy-in from relevant parties. The initial phase of this project involved gathering a wide range of ideas from affected groups on the question: how might Ontario's food movements advance existing efforts to promote health equity, dignified livelihoods, and justice with migrant farmworkers? Most of the data for this phase came from 11 in-depth interviews with key informants engaged in migrant farmworker employment in Ontario. We collected additional data through reviews of academic literature and civil society reports, as well as some participant observation. Interviews included people representing farmers and farm industry, public health, farmworker justice organizations, union labour, academia, and the provincial government. ${ }^{3}$ We sought to learn about the work of these organizations, their challenges, and their ideas for actionable ways through which the Ontario food system could become more equitable for farmers and farmworkers alike.

As part of Farmworker Awareness Week (March 24-31, 2015), Sustain Ontario published Know Farmworkers, Know Food, a seven-part blog series that focused on a set of key solution ideas gathered through our interviews. Some articles in the series were reblogged by Justicia for Migrant Workers, a transnational volunteer-based organization that promotes the rights of migrant farmworkers in Canada. Interview transcripts were analyzed through line-by-line thematic coding to identify recurrent or prominent solution themes. While they are not included as part of the formal data set, additional data were collected by gathering feedback on the blog series through a survey; social media conversations; and an interactive workshop as part of a conference that included academics, farmers, food justice and farming groups, and a nonprofit dedicated to farm labour.

\section{Key Solution Ideas}

The major solution ideas that informants proposed for Ontario food movements to collaborate on advancing farmworker health equity, livelihood quality, and justice were organized into four broad thematic areas: (a) health and safety, (b) farmworker recruitment and mobility, (c) communitybuilding and social integration, and (d) immigration

\footnotetext{
${ }^{3}$ While we attended a public tour that included migrants, we did not interview farmworkers themselves. This was due in part to the timing of the project during the farming off-season and the logistical difficulties of reaching rural areas. In addition, migrant farmworkers represent a higher-risk group for research because language barriers may be a factor and because of their precarious, "deportable" immigration status.
} 
policy. In this section we outline each one. While these proposed solutions emerge from Ontarian and Canadian policy contexts, many of the broad principles, such as greater social recognition of farmworker contributions and advocacy for immigration reform, are highly relevant to food movements elsewhere.

\section{Health and Safety}

Initiatives to advance farmworker health and safety are strongly grounded in the priorities voiced by farmworkers, along with a wealth of evidence about farmworker health and safety inequities in Ontario and accompanying proposals for policy solutions (McLaughlin, Hennebry, Cole, \& Williams, 2014; Pysklywec, McLaughlin, Tew, \& Haines, 2011). Numerous collaborative farmworker health initiatives involving academics, health practitioners, and civil society groups have made headway in Ontario, such as migrant farmworker health clinics that have been granted pilot funding by provincial health authorities. Furthermore, such initiatives present the advantage of appearing probusiness and relatively neutral in political terms. As one informant involved in a farmworker health equity project articulated, "Farm owners understand that a healthy workforce is a productive workforce. We should use this as an opportunity to bring farm owners/employers on board to champion this message" (Interview, November 26, 2014).

Some informants suggested that food movements could advance farmworker health equity through advocacy for improved accessibility of rural health services targeted at migrants, such as specialized clinics and mobile health units. Furthermore, one farm employer was adamant about changing immigration and employment insurance policies for migrants who become ill or injured:

In the case of illness, don't repatriate them until they're fully treated.... If they get sick, they should stay until they are fully recovered and no longer require medical care. Because in Jamaica, they do not have free medical care, they have to pay for it. And since they are paying employment insurance premiums and not able to collect...either don't take it from them, or give them rights to it. You know, it's not right for them to pay into a system that they do not benefit from. Because if they are unable to work for two weeks, they're repatriated. They must be repatriated. We, as employers, don't even have a choice on that. (Interview, October 29, 2014)

In addition, informants suggested establishing a standardized health and safety orientation and "welcome package" (including migrants' health cards). One informant indicated that Canada Border Services Agency could facilitate a workshop on migrant health and safety rights immediately upon their arrival in Canada. However, third-party organizations such as the Red Cross or Doctors Without Borders might be better placed to lead an orientation of this kind.

A further opportunity for advocacy concerns is the Employment Standards Act, which came under provincial government review in 2015 for its relevance to newer and more precarious forms of work. A summary of policy points from this study was presented to the Ministry of Labour as part of its Changing Workplaces Review public consultation process. This review coincided with a 2013 challenge from the provincial Ministry of Agriculture for the agri-food sector to double its annual growth rate and generate 120,000 jobs by 2020 (Ontario Ministry of Agriculture, Food and Rural Affairs [OMAFRA], 2015). When we inquired with a representative of the Ministry of Agriculture, however, it was unclear how the government might ensure or measure the quality of these proposed jobs. This potential inconsistency presents an opportunity to align government efforts to create more agri-food jobs with efforts to ensure that those jobs are healthy, well-protected, and provide liveable wages.

\section{Farmworker Recruitment and Mobility}

A second critical area for advocacy raised by informants involves farmworkers' inability to leave abusive or otherwise undesirable employment arrangements without risking unemployment, deportation, and the loss of future job opportunities in Canada. For instance, one farmer proposed that farmworkers should have the option of switching farm 
employers and the option of selecting particular farms where they would like to work: "While they are not legally prohibited from requesting work on a different farm, the system is set up in such a way that it almost negates that right" (Interview, October 29, 2014). This aligns with calls from migrant advocacy organizations for farmworkers to be granted open work permits (i.e., not job-specific or requiring proof that employers tried to hire locals first) rather than permits that are tied to specific employers.

A related suggestion for advocacy pertains to newer and increasingly popular non-SAWP streams of the TFWP. In the case of the SAWP, consulates or liaisons are theoretically responsible for mediating worker-employer conflicts, helping farmworkers access their rights and benefits, assisting with transfers to other jobs, and arranging repatriation of workers. Without a bilateral agreement between sending and receiving countries, farmworkers hired under non-SAWP streams of the TFWP do not have consulates or liaisons appointed to ensure their rights. Consequently, scholars and activists have warned that these nonSAWP streams leave farmworkers more vulnerable. Non-state private-interest groups who oversee labour recruitment may subject workers to disciplining (Valarezo, 2014). In other cases, private recruiters who oversee job recruiting may illegally charge migrants a fee for a job that does not exist, leaving them in debt (Faraday, 2014). To this end, Ontario could adopt legislation similar to Manitoba's Worker Recruitment and Protection Act, which proactively prevents extortion by recruiters (Faraday, 2014).

\section{Community-Building and Social Integration}

Suggestions to advance community-building among farmworkers and resident communities bear affinity with many of the activities in which Ontario's food movements are already engaged. These include building networks, establishing coops and community gardens, and promoting the social recognition of migrant farmworkers alongside other local producers. Over the long term, such efforts could serve to debunk racial and cultural stereotypes about migrant workers, provide opportunities for mutual learning of new languages, and support efforts to welcome migrant workers as full community members rather than as labourers alone. Existing efforts to strengthen linkages between urban food movement initiatives and rural farmworkers include director-producer Min Sook Lee's (2012) documentary about a migrant farmworker meeting with homeless youth who grow their own food in a Toronto community garden. This story exemplifies how groups of people who face distinct forms of marginalization in the food system can find common ground in their struggles against poverty and toward dignity.

Some rural Ontario towns have experienced racial conflict and power imbalances between migrant farmworkers and year-round residents. In the greenhouse and tomato-producing town of Leamington, the Ontario human rights tribunal in 2013 ordered a local greenhouse owner to pay $\mathrm{CA} \$ 23,500$ to a former migrant farmworker who was found to have been subject to racist slurs by a supervisor. That same year, the mayor singled out Jamaican farmworkers for allegedly sexually harassing local women and thereby spreading a "cancer" in the town (Boesveld, 2013). In order to promote inclusivity between farmworkers and year-round residents, one informant suggested strategies to highlight the vital economic contributions of farmworkers to rural communities. For instance, this might involve mayors of rural towns hanging a welcoming banner each season or profiling farmworkers in local agri-food and tourism marketing materials. In addition, a farmer-friendly organization like Sustain Ontario could reach out to municipal agricultural county committees to increase their awareness of resources for farmworker employees, such as rural health-related resources of which many employers may be unaware. A migrant activist noted that some farmworkers bring seeds and seek spaces to grow some of their own culturally relevant food while in Canada. She commented, "In many of the regions where migrant workers work...there's all of these community tensions between migrants and non-migrants, and animosity between the two groups. So how about a community garden? Could that bring people together?" (Interview, January 19, 2015). The same informant proposed establishing a farming co-op in which farmworkers who wished to stay in 
Canada would collaborate as member-owners. She emphasized that this workplace business model would allow workers to have "more of a say in what goes on, what happens; they have more of a say in what they do with their hands. That way, they are not so alienated from their own work" (Interview, January 19, 2015).

Beyond community-building at the level of individual communities and among farmworkers, one informant cited the need for convening a network of farmworker allies across the province. Rather than creating additional work for participants, such a network could serve as a venue for sharing challenges and successful strategies, avoiding duplication of efforts, and pooling resources toward common causes to advance farmworker health and justice. Existing networks such as Ontario's Migrant Worker Health project might serve as an important starting point for a broader network of this kind.

\section{Immigration Policy}

Several informants, including a farm employer, migrant justice group members, and a union leader, stated that migrant farmworkers should have the option of becoming permanent residents or citizens (e.g., having the option of applying for permanent residency, or receiving permanent resident status on arrival along with the regularization of immigration status for all current migrants in Canada). The national coordinator of the United Food and Commercial Workers (UFCW) union noted that in provinces outside Ontario and in industries other than agriculture, the UFCW has successfully negotiated a mandatory stipulation in workers' collective agreements for employers to nominate migrants for permanent residency through the Provincial Nominee Program (PNP). However, as noted earlier, current legislation in Ontario does not permit any farmworkerswhether migrants or permanent residents/citizens - to join a union. Some informants argued that farmworkers should have this option.

In addition, some informants called for an end to the aforementioned 4-and-4 Rule. Scholars and migrant-rights activist organizations have argued that this rule is racially discriminatory and treats workers as disposable. They contend that the rule unfairly forces non-SAWP workers to sever relationships they have built in Canada over four years, may incentivize visa overstaying in order to pay off recruiter debts, and perpetuates the inaccurate idea that migrant employment regimes are temporary (Keung, 2015). An unexpected finding from our study was that farm commodity organizations like Mushrooms Canada, which represents farmers who depend on year-round employees, were also protesting the 4-and-4-Rule, and calling for migrants to have access to permanent residency because they had invested significantly in workers' job training.

\section{Discussion}

\section{The Spaces and Constraints of Working Under a "Big Tent"}

The four thematic areas of solution ideas represent preliminary findings that require additional research to assess their feasibility among food movements and possibility of implementation. Further research is also required to assess how this study might build on the success of other related farmworker health and justice equity initiatives (Weiler et al., 2015). For instance, a notable area of potential advocacy that was not raised in our interviews would involve confronting the power of major food purchasers to shape working conditions and wages down the food chain. Initiatives such as the Coalition of Immokalee Workers in Florida have made important headway in harnessing the power of major food retailers and fast-food companies to ensure better wages for farmworkers, farmworker-driven monitoring and enforcement of workplace conditions, and zero tolerance for modern-day slavery (Asbed \& Sellers, 2013). Through additional workshops and conferences, subsequent phases of this ongoing project have been focused on collaboratively prioritizing particular solution areas and identifying actors who are committed to advancing them.

To that end, Sustain Ontario's big tent mandate to encourage collaboration across a wide range of affected network groups presents notable tensions. Sustain Ontario's reputation for representing moderate, balanced perspectives has enabled it to build strategic rapport with prominent government 
and industry actors. In some cases, this can generate pressure to de-emphasize solution ideas for farmworker health and justice concerns that might appear unfeasible in the eyes of certain groups or overly polarizing, such as the proposal that farmworkers should have the option of unionizing in Ontario or receive landed immigrant status upon arrival in Canada. In the climate of "advocacy chill" in Canada (Evans \& Shields, 2014), Sustain Ontario has faced restrictions on the kind and extent of political advocacy in which it can engage.

More specifically, Sustain Ontario faces internal pressure to prioritize the interests- with the associated funding grants — of its paid membership, which includes many farmers and farming organizations, but does not yet include farmworker groups. While the economic viability of Ontario farmers and local food availability undoubtedly depends on hired farmworkers, some members of Sustain Ontario nonetheless perceive farmworkerrelated initiatives as organizational "mission creep." A commitment to championing local farmers can clash, on occasion, with efforts to simultaneously support farmworkers. For example, farm employers might view campaigns to increase the farmworker minimum wage and overtime and vacation compensation as exacerbating an existing "costprice-squeeze" (Barnetson, 2009). That is, farm operators often explain that they face rising costs with diminishing returns, and minimizing labour costs and/or eliminating farm jobs through laboursaving technologies becomes one of the key strategies for remaining viable. In the words of one informant from a farming organization, "If you're a farm employer and you're not trying to figure out how to kill a job, you might be in trouble" (Interview, October 24, 2014).

Furthermore, in discussing features of Canada's temporary farmworker arrangement that make workers systemically vulnerable (e.g., the arbitrary power that employers hold over farmworkers' on-site living accommodations), farm operators may interpret systemic critiques as unfounded personal attacks or overgeneralized slander. Such conflicts reflect, in large measure, dominant systems of private property and racial/ citizenship privilege that disproportionately advantage farm employers with Canadian citizenship or permanent residency. We contend, however, that food movements can play an important role in supporting efforts such as those described by interview informants, including pay equity policies within small enterprises or co-operatively owned farming ventures. However modest, such projects would help to give substance to possibilities for food production beyond a zero-sum system of capitalist power and profit that sets farmers and farmworkers against one another.

While working toward a food system that fundamentally supports equal access to material and social resources necessary for all people to thrive, it is critical not to paint over differences of power across affected groups. As a long-term struggle, equalizing differences of power between migrant farmworkers and Canadian residents would entail not only providing full immigration status to migrant workers, but also addressing racialized and gendered global inequalities. Amidst the necessarily messy interim process of working toward justice, network-based food organizations might play a strategic function in identifying and mediating the advancement of common ground across sectors, scales, and places. As suggested by one of the study's informants, provincial food network organizations like Sustain Ontario might help to raise awareness among farm employers of existing migrant farmworker health resources in rural areas and build support for additional health resources. Public health has been a major area of focus among community food-security initiatives and networks across North America (Seed, Lang, Caraher, \& Ostry, 2013). As such, there is considerable scope for health-focused food networks to support existing migrant farmworker health projects, particularly given the pro-business basis and relative political neutrality of such initiatives. Because it does not require participants to adopt the identical political analysis of their shared problems in the food system, operating as a broadbased network in its ideal form can allow for relationships of trust and opportunistic coalitionbuilding where they might not otherwise occur.

Still, reformist approaches that merely seek to ameliorate the harsher edges of the status quo present a risk of reifying systems of food production, political economy, and immigration that are 
fundamentally inequitable and environmentally destructive. Food networks at large have often struggled to shift from reformist initiatives to transformative movements that can generate systemic change to ensure that benefits and harms of the food system are distributed more equitably across society and the environment (Holt-Giménez \& Shattuck, 2011). Thus it is important to be attuned to strategic political moments in which affected groups, who might differ in ideology but share similar values or goals, can lend themselves to enduring and transformative social change. For instance, our finding that some farm commodity groups are advocating for access to citizenship for farmworkers may present possibilities, however tenuous, for collaboration with migrant justice groups advocating for landed status on arrival and regularization of status. Building on calls for migrant citizenship rights in the People's Food Policy and farmworker justice workshops at Food Secure Canada's previous biannual assemblies, food network organizations across Canada might continue to convene spaces for national or even transnational discussion and action with groups implicated in farm employment.

\section{Community-University Partnerships on a Polarizing Research Issue}

Community-based research partnerships offer benefits to both researchers and community partners (Levkoe et al., 2016). From the perspective of Sustain Ontario, this partnership has offered increased capacity to conduct relevant and applicable research on an often underresourced and controversial subject area. Working with university-based researchers offered the community partner an opportunity for a rich engagement with less recognized food movement actors, and for greater traction and awareness among member organizations regarding an underrepresented yet important issue for the alliance. It also provided a better understanding of the barriers and opportunities presented by possible solutions on which to focus advocacy efforts. By working with university-based researchers, Sustain Ontario was able to approach a somewhat polarizing issue through a buffer of academic curiosity. Misunderstandings or potentially damaging characterizations, in theory, could be attributed to the researchers or academic institution rather than being directly associated with the community partner. The arms-length position of the researchers also offered the freedom to ask more critical questions of members of the alliance than the community partner might be able to.

The researchers benefited greatly from the reputation, connections, contacts, and reach of a network organization such as Sustain Ontario. In many cases, the researchers also offered a wealth of information, theoretical framing, and contacts. In this study both the graduate student and the instructor had a focus on equity and labour in agriculture and brought their experience, skills, and knowledge to the project. Community-based research partnerships appear best suited when research interests align closely with organizational mandates and the researcher is committed to collaborative communication.

As a corollary to these benefits, there is a risk of associating specific research findings with the aims of a community partner. Sustain Ontario is accountable to its membership and its mandate. As an organization, it has a specific brand or voice that it seeks to present in order to maintain credibility and often fundability. Academic research, on the other hand, is built on a principle of documentation and rigour that aims to disclose findings that are inclusive and complete. These goals can lead to a tension between what community partners are willing to publish and/or adopt and what academics offer as "data." It can also put some relationships cultivated by the community partner at risk if the critical questions and views of the researcher become conflated with those of the organization. If there is a conflict in approaches, researchers may feel controlled or censored by the organization. However, as in this study, a mutual respect for knowledge and a consistent commitment of the researcher to communicate can create a stronger, more insightful and potentially more applicable research outcome for both the community partner and the research institution.

\section{Conclusion}

As one node in the network of efforts to address social injustices and environmental crises in the food system, community-university partnerships 
offer unique strengths for approaching the equity challenges of farm labour regimes. Projects involving academics who have the time, resources, and skills to conduct research, working in collaboration with organizational actors with grounded experience and established relationships, offer a powerful opportunity to affect attitudes, programs, and policies. In this study, however, a notable limitation in terms of transformative potential has been the lack of involvement of migrant farmworkers themselves. We contend that in order to meaningfully reverse the conditions that make farmworkers disproportionately vulnerable to social and economic inequalities and poor health, farmworkers must have the opportunity to participate in authoring such changes. At present, migrant farmworker deportability and job precariousness make participation tremendously difficult. Diverse coalitions committed to advancing justice and economic viability in the food system, however, can help to create political spaces for farmworkers to participate in decisions affecting their lives. As part of this ongoing project, we intend to create additional spaces for farmworker participation in identifying priorities and taking collaborative action to advance their goals. Ensuring conditions of equity and dignity for farmworkers will help to create a food system that better enables everyone to thrive.

\section{Acknowledgements}

We are appreciative of all research informants for contributing their knowledge as part of this project, along with those who shared their perspectives as readers of the blog series and participants in a workshop at the 2015 Canadian Association for Food Studies Assembly in Ottawa, Ontario. Thank you to Heidi Tripp for assisting with the transcription of several interviews. We also thank Jenn Kucharczyk, Sustain Ontario program and communications coordinator, and professors Shauna Brail and Amrita Daniere of the Planning for Change course at the University of Toronto.

\section{References}

Alkon, A. H. (2014). Food justice and the challenge to neoliberalism. Gastronomica: The Journal of Food and Culture, 14(2), 27-40. http://dx.doi.org/10.1525/gfc.2014.14.2.27

Asbed, G., \& Sellers, S. (2013). The Fair Food Program: Comprehensive, verifiable and sustainable change for farmworkers. University of Pennsylvania Journal of Law and Social Change, 16(1), 1-10. Retrieved from http://scholarship.law.upenn.edu/ilasc/vol16/ iss $1 / 3$

Barnetson, B. (2009). The regulatory exclusion of agricultural workers in Alberta. Just Labour: $A$ Canadian Journal of Work and Society, 14, 50-74. Retrieved from http://www.justlabour.yorku.ca/ volume14/pdfs/04 barnetson presss.pdf

Barnetson, B. (2012). No right to be safe: Justifying the exclusion of Alberta farm workers from health and safety legislations. Socialist Studies, 8(2), 134-162. Retrieved from https://ejournals.library.ualberta. ca/index.php/sss/article/viewFile/23549/17433

Basok, T., Bélanger, D., \& Rivas, E. (2014).

Reproducing deportability: Migrant agricultural workers in South-western Ontario. Journal of Ethnic and Migration Studies, 40(9), 1394-1413. http://dx.doi.org/10.1080/1369183X.2013.849566

Baumann, S., Engman, A., \& Johnston, J. (2015). Shopping for change? Political consumption, conventional politics, and high cultural capital. International Journal of Consumer Studies, 39(5), 413421. http://dx.doi.org/10.1111/ijcs.12223

Binford, L. (2009). From fields of power to fields of sweat: The dual process of constructing temporary migrant labour in Mexico and Canada. Third World Quarterly, 30(3), 503-517. http://dx.doi.org/10.1080/01436590902742297

Binford, L. (2013). Tomorrow we're all going to the harvest: Temporary foreign worker programs and neoliberal political economy. Austin: University of Texas Press.

Boesveld, S. (2013, September 10). Mayor of Leamington, Ontario, says sexual harassment from migrant workers a 'cancer' on the town. National Post. Retrieved from http://news.nationalpost. $\mathrm{com} /$ news/canada/mayor-of-leamington-ontariosays-sexual-harassment-from-migrant-workers-acancer-on-the-town 
Bradley, K., \& Herrera, H. (2015). Decolonizing food justice: Naming, resisting, and researching colonizing forces in the movement. Antipode, 48(1), 97-114. http://dx.doi.org/10.1111/anti.12165

Brown, S., \& Getz, C. (2008a). Privatizing farm worker justice: Regulating labor through voluntary certification and labeling. Geoforum, 39(3), 1184-1196. http://dx.doi.org/10.1016/j.geoforum.2007.01.002

Brown, S., \& Getz, C. (2008b). Towards domestic fair trade? Farm labor, food localism, and the "family scale" farm. GeoJournal, 73(1), 11-22. http://dx.doi.org/10.1007/S10708-008-9192-2

Brown, S., \& Getz, C. (2015). Domestic fair trade in the United States. In L. T. Raynolds \& E. A. Bennett (Eds.), Handbook of research on fair trade (pp. 174-190). Cheltenham, UK.

Citizenship and Immigration Canada [CIC]. (2015). Fact sheet: Temporary foreign worker program. Ottawa: Author. Retrieved from http://www.cic.gc.ca/english/ resources/publications/employers/temp-foreignworker-program.asp

Ekers, M., Levkoe, C. Z., Walker, S., \& Dale, B. (2015). Will work for food: Agricultural interns, apprentices, volunteers, and the agrarian question. Agriculture and Human Values. Advance online publication. http://dx.doi.org/10.1007/s10460-015-9660-5

Employment and Social Development Canada [ESDC]. (2014). Labour market opinions-annual statistics: Number of temporary foreign worker positions on positive labour market impact assessments (LMLAs) under the agricultural occupations, by location of employment. Ottawa: Government of Canada, ESDC. Retrieved from http://www.esdc.gc.ca/en/foreign workers/hire/ seasonal agricultural/documents/caribbean.page

ESDC. (2015a). Agreement for the employment in Canada of Commonwealth Caribbean seasonal agricultural workers2015. Ottawa: Government of Canada, ESDC. Retrieved from http://www.esdc.gc.ca/eng/jobs/ foreign workers/agriculture/seasonal/sawpcc2015. shtml

ESDC. (2015b). Agricultural workers-Comparison of program options and criteria. Ottawa: Government of Canada, ESDC. Retrieved from http://www.esdc. gc.ca/eng/jobs/foreign_workers/agriculture/ comparison.shtml

Evans, B., \& Shields, J. (2014). Nonprofit engagement with provincial policy officials: The case of NGO policy voice in Canadian immigrant settlement services. Policy and Society, 33(2), 117-127. http://dx.doi.org/10.1016/j.polsoc.2014.05.002

Faraday, F. (2014). Profiting from the precarious: How recruitment practices exploit migrant workers. Summary report. Toronto: The Metcalf Foundation. Retrieved from http://metcalffoundation.com/stories/ publications/profiting-from-the-precarious-howrecruitment-practices-exploit-migrant-workers/

Food Secure Canada. (2015). Resetting the table: A People's Food Policy for Canada. $2^{\text {nd }}$ ed. Montreal, Quebec: Food Secure Canada. Retrieved from http://foodsecurecanada.org/sites/default/files/ fsc-resetting-2015_web.pdf

Friedmann, H. (2007). Scaling up: Bringing public institutions and food service corporations into the project for a local, sustainable food system in Ontario. Agriculture and Human V alues, 24(3), 389398. http://dx.doi.org/10.1007/s10460-006-9040-2

Gibb, N., \& Wittman, H. (2013). Parallel alternatives: Chinese-Canadian farmers and the Metro Vancouver local food movement. Local Environment, 18(1), 1-19. http://dx.doi.org/10.1080/13549839. $\underline{2012.714763}$

Gray, M. (2014). Labor and the locavore: The making of a comprehensive food ethic. Berkeley and Los Angeles: University of California Press.

Guthman, J. (2007). The Polanyian way? Voluntary food labels as neoliberal governance. Antipode, 39(3), 456-478. http://dx.doi.org/10.1111/j.1467$\underline{8330.2007 .00535 . x}$

Hennebry, J. (2012, February 23). Permanently temporary? Agricultural migrant workers and their integration in Canada. Summary. Montreal, Quebec: Institute for Research on Public Policy. Retrieved from http://irpp.org/research-studies/study-no26/

Hjalmarson, E., Bunn, R., Cohen, A., Terbasket, E., \& Gahman, L. (2015). Race, food, and borders: Situating migrant struggle in the Okanagan Valley, British Columbia. Journal of Agriculture, Food Systems, and Community Development, 5(4), 77-82. http://dx.doi.org/10.5304/jafscd.2015.054.007

Holt Giménez, E., \& Shattuck, A. (2011). Food crises, food regimes and food movements: Rumblings of reform or tides of transformation? Journal of Peasant Studies, 38(1), 109-144. http://dx.doi.org/10.1080/03066150.2010.538578 
Johnston, J. (2008). The citizen-consumer hybrid: Ideological tensions and the case of Whole Foods Market. Theory and Society, 37(3), 229-270. http://dx.doi.org/10.1007/S11186-007-9058-5

Keung, N. (2015, March 27). Mass ejection of temporary foreign workers looms. Toronto Star. Retrieved from http://www.thestar.com/news/immigration/2015/ 03/27/mass-ejection-of-temporary-foreignworkers-loomsmass-ejection-of-temporary-foreignworkers-looms.html

Lee, M. S. (Producer/Director). (2012). Teo in Toronto. Toronto: Ontario Educational Communications Authority, TVO. Retrieved from http://tvo.org/ video/programs/why-poverty-ontario-shortdocumentaries/teo-in-toronto

Levkoe, C. Z. (2014). The food movement in Canada: A social movement network perspective. Journal of Peasant Studies, 41(3), 385-403. http://dx.doi.org/10.1080/03066150.2014.910766

Levkoe, C. Z. (2015). Strategies for forging and sustaining social movement networks: A case study of provincial food networking organizations in Canada. Geoforum, 58, 174-183. http://dx.doi.org/10.1016/i.geoforum.2014.11.013

Levkoe, C. Z., McClintock, N., Minkoff-Zern, L.-A., Coplen, A. K., Gaddis, J., Lo, J., Tendick-Matesanz, F., \& Weiler, A. M. (2016). Forging links between food chain labor activists and academics. Journal of Agriculture, Food Systems, and Community Development. Advance online publication. http://dx.doi.org/10.5304/jafscd.2016.062.009

McLaughlin, J. (2010). Classifying the "ideal migrant worker": Mexican and Jamaican transnational farmworkers in Canada. Focal, 2010(57), 79-94. http://dx.doi.org/10.3167/fcl.2010.570106

McLaughlin, J., \& Hennebry, J. (2013). Pathways to precarity: Structural vulnerabilities and lived consequences in the everyday lives of migrant farmworkers in Canada. In L. Goldring \& P. Landolt (Eds.), Producing and negotiating non-citizenship: Precarious legal status in Canada (pp. 175-194). Toronto: University of Toronto Press.

McLaughlin, J., Hennebry, J., Cole, D., \& Williams, G. (2014). The migrant farmworker health journey: Identifying issues and considering change across borders. Waterloo, Ontario: International Migration Research Centre. Retrieved from http://imrc.ca/ wp-content/uploads/2013/10/IMRC-PolicyPoints-VI.pdf
McLaughlin, J., Hennebry, J., \& Haines, T. (2014). Paper versus practice: Occupational health and safety protections and realities for temporary foreign agricultural workers in Ontario. Perspectives Interdisciplinaires Sur le Travail et la Santé, 16(2). Retrieved from https://pistes.revues.org/pdf/3844

Minkoff-Zern, L.-A. (2014). Challenging the agrarian imaginary: Farmworker-led food movements and the potential for farm labor justice. Human Geography, 7(1), 85-101. Retrieved from http://www.academia.edu/6076331/Challenging the_Agrarian_Imaginary_Farmworker_Led_Food_ Movements and the Potencial for Farm Labor Justice

Myers, J. S., \& Sbicca, J. (2015). Bridging good food and good jobs: From secession to confrontation within alternative food movement politics. Geoforum, 61, $17-26$. http://dx.doi.org/10.1016/i.geoforum.2015.02.003

Ontario Ministry of Labour [OML]. (2006). A guide to the Occupational Health and Safety Act for farming operations. Toronto: Ontario Ministry of Labour. Retrieved from http://www.labour.gov.on.ca/english/ hs/pubs/farming/ohsa/

OML. (2011). Special coverage and/or exemptions: Farm employees (other than harvesters and horse breeding/ boarding). Toronto: Ontario Ministry of Labour. Retrieved from http://www.labour.gov.on.ca/ english/es/tools/srt/coverage agriculture farm employee.php

Ontario Ministry of Agriculture, Food and Rural Affairs [OMAFRAM]. (2015). Ontario's local food report: 2014-2015. Toronto: Author. Retrieved from http://www.omafra.gov.on.ca/english/about/local food rpt.htm

Otero, G. (2011). Neoliberal globalization, NAFTA, and migration: Mexico's loss of food and labor sovereignty. Journal of Poverty, 15(4), 384-402. http://dx.doi.org/10.1080/10875549.2011.614514

Preibisch, K. (2012). Development as remittances or development as freedom? Exploring Canada's temporary migration programs from a rights-based approach. In F. Faraday, J. Fudge, \& E. Tucker (Eds.), Constitutional labour rights in Canada: Farm workers and the Fraser Case (pp. 81-108). Toronto: Irwin Law.

Preibisch, K. L., \& Grez, E. E. (2014). The other side of el Otro Lado: Mexican migrant women and labor flexibility in Canadian agriculture. Signs, 35(2), 289316. http://dx.doi.org/10.1086/605483 
Preibisch, K., \& Otero, G. (2014). Does citizenship status matter in Canadian agriculture? Workplace health and safety for migrant and immigrant laborers. Rural Sociology, 79(2), 174-199. http://dx.doi.org/10.1111/ruso.12043

Pysklywec, M., McLaughlin, J., Tew, M., \& Haines, T. (2011). Doctors within borders: Meeting the health care needs of migrant farm workers in Canada. Canadian Medical Association Journal, 183(9), 1039_ 1042. http://dx.doi.org/10.1503/cmaj.091404

Ramsaroop, C., \& Wolk, K. (2009). Can we achieve racial equality in the food security movement? In $\mathrm{C}$. Palassio \& A. Wilcox (Eds.), The edible city: Toronto's food from farm to fork (pp. 252-263). Toronto: Coach House Books.

Ramírez, M. M. (2014). The elusive inclusive: Black food geographies and racialized food spaces. Antipode, 47(3), 748-769. http://dx.doi.org/10.1111/anti.12131

Reid-Musson, E. (2014). Historicizing precarity: A labour geography of "transient" migrant workers in Ontario tobacco. Geoforum, 56, 161-171. http://dx.doi.org/10.1016/j.geoforum.2014.07.005

Satzewich, V. (2007). Business or bureaucratic dominance in immigration policymaking in Canada: Why was Mexico included in the Caribbean Seasonal Agricultural Workers Program in 1974? Journal of International Migration and Integration, 8(3), 255-275. http://dx.doi.org/10.1007/s12134-007-0026-8

Sbicca, J. (2015). Food labor, economic inequality, and the imperfect politics of process in the alternative food movement. Agriculture and Human Values, 32(4), 675-687. http://dx.doi.org/10.1007/s10460-0159582-2

Seed, B., Lang, T., Caraher, M., \& Ostry, A. (2013). Integrating food security into public health and provincial government departments in British Columbia, Canada. Agriculture and Human Values, 30(3), 457-470. http://dx.doi.org/10.1007/s10460013-9426-x

Smith-Nonini, S. (2013). Seeing no evil: The H2A guestworker program and state-mediated labor exploitation in rural North Carolina. In L. Allegro \& A. Wood (Eds.), Latin American migrations to the U.S. heartland: Changing social landscapes in Middle America (pp. 101-124). Urbana: University of Illinois Press.
Tucker, E. (2006). Will the vicious circle of precariousness be unbroken? The exclusion of Ontario farm workers from the Occupational Health and Safety Act. In L. Vosko (Ed.), Precarious employment: Understanding labour market insecurity in Canada (pp. 256-276). Montreal: McGill-Queen's Press.

Turje, M. (2012). Social workers, farmers and food commodification: Governmentality and neoliberalism in the alternative food movement. Canadian Social Work Review, 29(1), 121-138. Summary retrieved at http://www.scie-socialcareonline. org.uk/social-workers-farmers-and-foodcommodification-governmentality-andneoliberalism-in-the-alternative-food-movement/ r/a1CG0000000GPxeMAG

Valarezo, G. (2014). Offloading migration management: The institutionalized authority of non-state agencies over the Guatemalan Temporary Agricultural Worker to Canada project. Journal of International Migration and Integration, 16(3), 661-677. http://dx.doi.org/10.1007/s12134-014-0351-7

Verduzco, G., \& Lozano, M. I. (2003). Mexican farm workers' participation in Canada's seasonal agricultural labour market and development consequences in their rural home communities. Ottawa: North-South Institute.

Walia, H. (2010). Transient servitude: Migrant labour in Canada and the apartheid of citizenship. Race \& Class, 52(1), 71-84. http://dx.doi.org/10.1177/ $\underline{0306396810371766}$

Walia, H. (2013). Undoing border imperialism. Oakland, California: AK Press.

Weiler, A. M., Hergesheimer, C., Brisbois, B., Wittman, H., Yassi, A., \& Spiegel, J. M. (2015). Food sovereignty, food security and health equity: A meta-narrative mapping exercise. Health Policy and Planning, 30(8), 1078-1092. http://dx.doi.org/10.1093/heapol/czu109

Weiler, A. M., Otero, G., \& Wittman, H. (2016). Rock stars and bad apples: Moral economies of alternative food networks and precarious farm work regimes. Antipode. Advance online publication. http://dx.doi.org/10.1111/anti.12221 